\title{
The Behavior-before-Coding Principle in morphosyntactic change: evidence from verbal rather.
}

LSA annual meeting, Portland, Oregon, Jan. 5, 2012

Rachel Klippenstein

The Ohio State University

(klip@ling.ohio-state.edu)

\section{Introduction}

The English adverb rather, originally the comparative of the adverb rathe 'quickly, early' (OED s.v. rathe, adv.), has given rise to a new verb rather 'prefer', which can be observed in sentences such as 'They would have rathered her go hang out at parties'1 Verbal rather appears first without verbal morphology as far back as the late 1500s, but does not show verbal morphology until the late 1800s. This pattern of development is consistent with and thus supports Haspelmath's (2010) proposal that behavioral properties change before coding properties in broader contexts than just in the development of subject properties. However, the development of verbal rather is not a case of grammaticalization, so the proper generalization of the behavior-before-coding principle must not be restricted to grammaticalization.

In the 1920s, a few linguists took brief notice of this verbal rather; Moore et al. (1924) cite an example from Anglo-Manx, and Strong (1926) cites a (presumably) American example. Juge (2002) discusses verbal rather in more depth, citing data (all with verbal morphology) from the internet, and proposes a plausible scenario for the reanalysis of a verb rather out of phrases of the form I would rather VERB. He does not trace the early history of the word in any detail, and expects evidence for early stages to be unavailable due to the limited amount of pre-internet non-standard written text.

\section{Verbal rather without verbal morphology since the late $1500 \mathrm{~s}$}

Contrary to Juge's expectations, I have found substantial evidence for verbal rather from long before the internet, using Google Books to find examples. This is possible in part because Google Books includes more non-standard text than might be expected, and in part because verbal rather sometimes occurs in otherwise standard English texts. It is first attested in the late 1500s and early 1600s, in literary works (mostly from England) and letters (mostly from Scotland). In the following examples, rather does not show verbal morphology, but it is nevertheless clear that rather is syntactically a verb, either because it is the only possible verb between a matrix subject and an embedded subject, because it is the only possible verb between a subject pronoun and infinitive $b e$, or because it is the only possible verb between a subject pronoun and an object.

1. 1576 (or earlier). ${ }^{2}$ Richard Edwards, 'Of Fortunes power'.

I rather be borne Fortunate, then to be very wise. (Edwards 1576:25).

2. 1614. George Sinclair, $5^{\text {th }}$ Earl of Caithness, letter to Lord Binning.

Quhat cair and quhat panes and haisard I haue beine in since my comeing heir, I will remitt to vthers to declair; bot befoir it had not proceidit as it hath done, I rather I had bene buried heir. (Pitcairn 1833:290)

Attestations of verbal rather without verbal morphology continue through the $17^{\text {th }}-20^{\text {th }}$ centuries. In the $19^{\text {th }}$ century, they occur in a wide range of textual contexts, including fictional and anecdotal literature (usually in dialogue), letters, records of legal question-

\footnotetext{
${ }^{1}$ Heard by the author in February 2005.

${ }^{2}$ First published 1576, but the author died in 1566; if the text was not modified by the editor, the example is from 1566 or earlier.
} 
and-answer sessions, advertisements, academic and practical non-fiction, and dictionarylike entries. Here are a few examples:

3. 1825. Gaelic dictionary (Armstrong 1825:891)

RATHER, $a d v$. Docha, fearr ; càr, an àite, an àite sin, ni 's ro thoiliche. I rather you than him, is docha leam thusa no esan; I rather go than stay, is àille leam falbh, na fanachd; I had rather, b'àille leam, bu docha leam ; nay, rather, air àite sin.

4. 1839. The Botanico-Medical Recorder (Curtis 1839:110)

The Graham Journal and Library of Health are now one flesh, to be under the editorial direction of Dr. Alcott. We rather they would have continued in their state of single blessedness ...

\section{Verbal rather with verbal morphology since late $1800 \mathrm{~s}$}

In the 1890s, rather begins to be attested with verbal morphology. The clearest pre-1900 example occurs in Sinclair's (1899) edited version of the 1614 text given in (2) above. Sinclair cleans up spelling, morphology, word choice, and style towards norms of his time. In the process, he adapts I rather I had bene buried heir (without morphology) to I should have rathered I had been buried here (with morphology); this indicates that he in fact perceived should have rathered as relatively standard.

5. 1899. Thomas Sinclair's (1899:119) edition of George Sinclair's 1614 letter.

What care and what pains and hazard I have been in since coming here, I will remit to others to declare; but if the matter had not proceeded as it has done, I should have rathered I had been buried here. (Sinclair 1899:119)

By 1950, examples of rather with all possible English verbal inflections can be found, in texts with varying degrees of standardness.

6. 1924. Anglo-Manx dialect dictionary. (Moore et al. 1924)

One was prutty and one was or'nary, and of coorse he rathered the prutty one.

7. 1926. Observational note in American Speech; example from a freshman essay. When my brother finished high school he wanted to travel but my parents rathered he would stay at home. (Strong 1926)

8. 1934. Academic book review. (Nairne 1934)

He 'rathers nothing', but enjoys God and ensues peace and goodwill to man.

9. 1947. Fiction. (Naughton 1947:105)

"Tha can have it," said Rafe, "but I should have rathered tha were not beholden to Arthur Gaskett."

10. 1949. Fiction. (Bowen 1949:269)

So you must excuse my saying anything I did: all it was, that up to the very last I had understood us all to be friendly - apart, that is, from his rathering me not there.

\section{Behavioral and coding properties and the Behavior-before-Coding principle}

Keenan (1976), discussing different kinds of subject properties, made a distinction between behavioral properties and coding properties. Cole et al. (1980:719), modifying Keenan's classification slightly, define coding properties as 'morphosyntactic ... properties, e.g. nominative case and control of verb agreement' and behavioral properties as 'transformational ... properties, e.g. control of reflexivization and deletability by rules 
normally affecting only subjects'. Cole et al. argued that when a non-subject becomes a subject, 'behavioral subject properties ... are acquired historically prior to subject coding properties'

Haspelmath generalized the definitions of behavioral and coding properties beyond subject properties, defining coding properties of constructions as 'properties that are reflected in (inflectional) morphological distinctions, e.g., case, agreement morphology' and behavioral properties of constructions as 'syntactic properties without morphological reflexes'. With these definitions, he proposes the Behavior-before-Coding Principle as a generalization of Cole's diachronic hypothesis (Haspelmath 2010:544):

11. When a grammatical construction grammaticalizes, as a rule the behavioural properties change before the coding properties of the construction.

Haspelmath gives a number of cases that support this proposal, and calls for further investigation as to whether the Behavior-before-Coding Principle is a universal principle of morphosyntactic change or not.

\section{Verbal rather and the Behavior-before-Coding Principle}

The attestations of rather playing the verbal role in a sentence, but without verbal morphology, show verbal behavior but not verbal coding; these appear from the late 1500 s through to the present time. The attestations of rather with verbal morphology, beginning in the late 1800 s, show verbal coding properties. These examples thus show a behavior-before-coding pattern of development. This supports Haspelmath's idea that behavior-before-coding is not special to the development of subject properties, but occurs more broadly in morphosyntactic change.

However, Haspelmath frames his generalized Behavior-before-Coding Principle in terms of grammaticalization; the development of verbal rather is not a case of grammaticalization. Not only is the verb rather no more 'grammatical' than the adverb rather, but the semantics of the whole construction after reanalysis are no more 'grammatical' than before. The reanalysis creates new lexical material, not new grammatical material. As a result, verbal rather does not support Haspelmath's Behaviorbefore-Coding principle as stated. Rather, it suggests that the category that behaviorbefore-coding can be generalized to must be something besides grammaticalization.

It is not completely clear what this category should be, but one possibility is syntactic reanalysis. In a case of syntactic reanalysis, the context of reanalysis takes place within a frame with particular coding properties (or lack thereof); for instance, in the

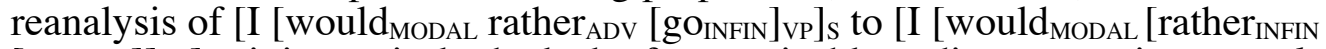
$\left.\left.\left[\mathrm{gO}_{\text {INFIN }}\right]\right]_{\mathrm{VP}}\right]_{\mathrm{S}}$, it is precisely the lack of recognizable coding properties on rather (no longer recognizable as comparative due to loss of positive form; see Juge 2002) and the

fact that infinitive verbs do not show coding that allows rather to be reinterpreted from an adverb to a verb. Thus, it is plausible that the initial reanalysis would not show coding distinctions, while later extensions of the reanalyzed form would eventually introduce coding distinctions.

\section{References:}

Armstrong, R. A. 1825. A Gaelic Dictionary. London: James Duncan. http://books.google.com/books?id=jyQ-AAAAcAAJ

Bowen, Elizabeth. 1949. The Heat of the Day. New York: Alfred A. Knopf.

Cole, Peter, Wayne Harbert, Gabriella Hermon, and S. N. Sridhar. 1980. 'The Acquisition of Subjecthood.' Language 56:719-743.

Curtis, A. (ed.) 1839. The Botanico-Medical Recorder, Vol. 8, No. 7. http://books.google.com/books?id=EwugAAAAMAAJ

Edwards, Richard. 1576. 'Of Fortunes power'. In The paradyse of daynty deuises, p. 24- 
25, ed. by M. Edwards [Richard Edwards]. London: Henry Disle.

Haspelmath, Martin. 2010. 'The Behaviour-before-Coding Principle in Syntactic

Change.' Essais de Typologie et de Linguistique Générale: Mélanges Offerts à Denis Creissels, ed. by Franck Floricic, 541-554. Lyon: Presses Universitaires de l'École Normale Superieure.

Juge, Matthew. 2002. 'Unidirectionality in Grammaticalization and Lexical Shift: The Case of English Rather'. Proceedings of the Annual Meeting of the Berkeley Linguistics Society. 28:147-154

Keenan, Edward L. 1976. 'Towards a Universal Definition of "Subject."' Subject and Topic, ed. by Charles N. Li, 303-333. New York: Academic Press.

Moore, A. W., Sophia Morrison, and Edmund Goodwin. 1924. A Vocabulary of the Anglo-Manx Dialect. Oxford: Oxford University Press.

Nairne, A. 1934. Review of Y a-t-il deux sources de la religion et de la morale?, by Alfred Loisy. The Journal of Theological Studies 35:397-398.

Naughton, Bill. 1947. Rafe Granite. London: Pilot Press.

Pitcairn, Robert. 1833. Ancient Criminal Trials in Scotland, Vol. 3, part 1. Edinburgh: Bannatyne Club. http://books.google.com/books?id=bqhBAAAAcAAJ

Sinclair, Thomas. 1899. Caithness Events : A Discussion of Captain Kennedy's Historical Narrative, and an Account of the Broynach Earls, $2^{\text {nd }}$ ed. Wick: W. Rae. http://books.google.com/books?id=sBcwAAAAMAAJ

Strong, Mabel. 1926. 'New Verbs'. American Speech 1:292. 